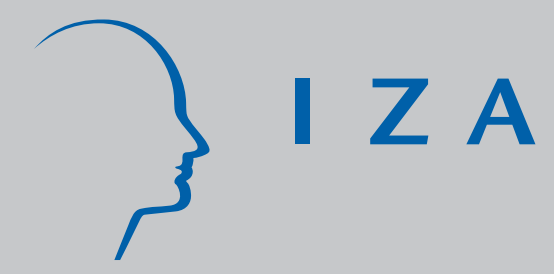

IZA DP No. 3118

Collateral Costs: The Effects of Incarceration on the Employment and Earnings of Young Workers

Harry J. Holzer

October 2007 


\title{
Collateral Costs: The Effects of Incarceration on the Employment and Earnings of Young Workers
}

\author{
Harry J. Holzer \\ Georgetown University, \\ Urban Institute and IZA
}

Discussion Paper No. 3118

October 2007

IZA

P.O. Box 7240

53072 Bonn

Germany

Phone: +49-228-3894-0

Fax: +49-228-3894-180

E-mail: iza@iza.org

\begin{abstract}
Any opinions expressed here are those of the author(s) and not those of the institute. Research disseminated by IZA may include views on policy, but the institute itself takes no institutional policy positions.

The Institute for the Study of Labor (IZA) in Bonn is a local and virtual international research center and a place of communication between science, politics and business. IZA is an independent nonprofit company supported by Deutsche Post World Net. The center is associated with the University of Bonn and offers a stimulating research environment through its research networks, research support, and visitors and doctoral programs. IZA engages in (i) original and internationally competitive research in all fields of labor economics, (ii) development of policy concepts, and (iii) dissemination of research results and concepts to the interested public.
\end{abstract}

IZA Discussion Papers often represent preliminary work and are circulated to encourage discussion. Citation of such a paper should account for its provisional character. A revised version may be available directly from the author. 
IZA Discussion Paper No. 3118

October 2007

\section{ABSTRACT}

\section{Collateral Costs: The Effects of Incarceration on the Employment and Earnings of Young Workers ${ }^{*}$}

In this paper I review the empirical evidence on the effects of incarceration on the subsequent employment and earnings of less-educated young prisoners. In this discussion I include evidence from: 1) Employer surveys and audit studies of hiring; 2) Survey data (mostly from the NLSY79) and administrative data; and 3) state-level incarceration data linked to micro employment data for young black men. The strengths and weaknesses of each type of analysis are discussed as well. The preponderance of the evidence considered suggests that, all else equal, spells of incarceration do tend to reduce subsequent employment and earnings for those with criminal records.

JEL Classification: J15, J2

Keywords: incarceration, employment, earnings

Corresponding author:

Harry J. Holzer

Georgetown Public Policy Institute

Georgetown University

3600 N St. NW, Ste. 202

Washington DC 20007

USA

E-mail: hjh4@georgetown.edu

\footnotetext{
* The author thanks Jeff Grogger, Steve Raphael, David Weiman and other seminar participants at the Russell Sage Foundation for helpful comments.
} 


\section{Introduction}

The enormous increases in incarceration that have occurred in the U.S. over the past few decades have no doubt generated major benefits and costs to society. On the one hand, they have likely reduced crime, at least to some extent, which generates a large benefit to society; on the other hand, it has cost enormous public sums to build and operate prisons in the U.S. (Donohue, this volume).

In addition, there are a range of "collateral” benefits and costs to the individuals who are incarcerated, their families/communities and others that need to be considered as well. For instance, the experience of incarceration could potentially have either positive or negative effects on the employment and earnings of offenders after their release. Incarceration might have a range of other effects on individuals as well - including their civic participation, voting behavior, access to public benefits, and the like. These, too, could have implications for their families and communities as well as themselves.

In this paper, I review what we know about the "collateral” costs and benefits of incarceration on earnings and employment. Partly I do so because these benefits and/or costs have been the subject of much more research to date than the collateral effects along other dimensions. But another reason to focus on employment is that these effects are extremely important. For one thing, the employment of ex-offenders is quite negatively correlated with their tendency to re-offend and recidivate; and, at least to some extent, this effect appears to be causal (Raphael and Weiman, 2007). Indeed, of the roughly 650,000 inmates who are released from jail or prison each year, a majority recidivate within 3-5 years (Travis, 2003); and, for those who do not "reenter" 
successfully, the costs to the individual, his/her family, and society are very large. ${ }^{1}$ Even among those who do not recidivate, employment outcomes are correlated with (and perhaps causally related to) health and other measures of their own well-being. Employment prospects and outcomes after incarceration thus appear to be major determinants of whether or not ex-prisoners "reenter" civil society successfully, and of the myriad costs to the individual and to society when reentry is unsuccessful.

In the paper below I first lay out the potential effects of incarceration on both the demand for labor (by employers) and its supply (among potential workers). These effects can, in theory, be either positive or negative. I then explore the different studies on this topic, focusing on the data sources and empirical methods used, and on the magnitudes of the effects generated. In doing so, I hope to reconcile conflicting results, and generate a useful summary of what we know. The studies based on workers include those using individual data, either from surveys or from administrative sources; as well as more aggregated data. I then conclude the paper with a summary of what we know and its implications both for research and public policy.

I will argue below that, while the credible empirical evidence is quite mixed, the preponderance of it points to negative effects of incarceration on the subsequent employment and earnings of offenders. By reducing their employment prospects, these effects likely raise recidivism rates of released offenders, which impose further costs on society (in the form of both crime and incarceration expenditures). Policies designed to reduce these collateral costs, either through direct reductions in incarceration rates or in

\footnotetext{
${ }^{1}$ Ludwig (2006) has argued that the aggregate costs of crime and incarceration to the U.S. might be as high as $\$ 2 \mathrm{~T}$ per year, and a large fraction of this cost appears to be associated with repeat offenders.
} 
their negative effects on subsequent earnings, might therefore generate positive benefits to the individuals in question and to society more broadly.

\section{Effects of Incarceration on Subsequent Earnings: Theoretical Considerations}

When individuals are incarcerated and subsequently released, why should we expect their incarceration to potentially impact their later employment and earnings? ${ }^{2}$ Figure 1 lays out a range of possible effects, both positive and negative. These effects could operate through the employment and earnings of the incarcerated individuals themselves - whether before, during or especially after incarceration; and also on the employment outcomes of certain non-prisoners as well. Furthermore, they could operate through the attitudes and hiring behaviors of employers, on the demand side of the labor market; as well as those of potential job applicants and workers on the supply side of that market.

A number of important considerations appear in Figure 1. Any positive effects that incarceration might have on employment would operate primarily through their deterrence effects on criminal behavior, primarily after incarceration for those who engage in crime and more generally for those who do not (but who, in the absence of potential incarceration, might choose to do so). ${ }^{3}$ To the extent that incarceration might actually help previous offenders organize their lives (Nagin and Waldfogel, 1995) and

\footnotetext{
${ }^{2}$ For some other discussions of these effects see Sampson and Laub (1993 ) or Western (2006).

${ }^{3}$ The most widely accepted economic models of crime (Becker, 1968; Freeman, 1999) suggest that individuals choose between "legal" and "illegal" employment, depending on the relative costs and returns associated with each type of activity. Since incarceration raises the costs of participating in crime, it should reduce the percentage of individuals making this choice, and thereby raise the percentage choosing legitimate work. The notion that there is a tradeoff between employment and crime is quite clearly supported by the evidence, as Freeman's paper shows. Even among those who engage in crime and ultimately become incarcerated, it is possible that the perceived risks of incarceration reduce the frequency or severity of the crimes they commit.
} 
even enhance their educational credentials, perhaps by obtaining a GED (e.g., Tyler and Kling, 2007), these positive effects would be enhanced. The evidence by Kling (2006) of positive short-term effects of length of incarceration on post-prison employment outcomes (which I discuss more fully below) is certainly consistent with this view.

But there are a number of reasons to believe that incarceration might have negative effects on employment as well. Clearly, incarceration will directly reduce employment during the period of imprisonment (by incapacitating the offender), assuming that the offenders might have engaged in at least some positive work experience in the absence of their incarceration. Since most survey and administrative evidence show significant work activity for individuals in the periods directly prior to their incarceration (e.g., Travis, 2004), it seems likely that some would have been at least partly employed had they not been imprisoned.

Once released, the tendency of ex-prisoners to work might be reduced for a variety of supply-based reasons, such as the fact that their skills (or "human capital”) depreciate over time, their information about the job market weakens and their work networks atrophy. ${ }^{4}$ As these individuals withdraw from the labor market (and perhaps recidivate), their behavior can also reduce the opportunities for and interest in employment among young men in poor neighborhoods who otherwise might not engage in crime (e.g., Wilson, 1996) - perhaps by thinning out their informal employment networks as well or by generating more negative peer effects.

\footnotetext{
${ }^{4}$ The importance of informal networks in generating employment has long been emphasized by both economists and sociologists - see, for instance, Rees (1966) and Granovetter (1974). The particular importance of these weakened informal networks for the employment opportunities of young black men was emphasized in Holzer (1987). The empirical evidence on the role of these networks more broadly is summarized in Ioannides and Datcher Loury (2004).
} 
A potentially important effect of prior incarceration on incentives to work might also operate through the child support system. According to Holzer et al.(2004), the vast majority (i.e., roughly 70\%) of men released from prison are non-custodial fathers. These men are subject to much more rigorous child support enforcement policies that have been implemented throughout the 1980’s and 1990’s (Mincy and Sorensen, 1998; Garfinkel, 2001).

Even absent incarceration, these policies could have either positive or negative effects on work incentives (Edelman et al., 2006; Holzer et al., 2005). On the one hand, the pressure to generate payments, and the risk of punishment for those who do not do so, creates positive incentives to work. But, on the other hand, the tax rates on earnings generated by the child support system reduce these incentives, especially in states where punishments for non-payment are not rigorously enforced. According to standard labor supply theory in economics (e.g., Ehrenberg and Smith, 2000), one’s willingness to work depends on the wages available, net of taxes, and also on one's "elasticity of labor supply,” which measures the responsiveness of work effort to these net wages. Much available evidence (e.g., Juhn et al., 1991; Grogger, 1998; Katz, 1998) suggests that, for low-wage men, labor supply is indeed responsive to these net wages. Furthermore, the tendency of some states to withhold payments from families and children who have been on public assistance further limits the incentives of non-custodial fathers to make these payments, as their own children do not necessarily benefit from their doing so - making the analogy of the child support order to a tax on earnings even stronger. ${ }^{5}$

\footnotetext{
${ }^{5}$ The Personal Responsibility and Work Opportunity Act (PRWOA) of 1996, which constituted the federal government's effort to reform welfare, contained a number of child support provisions that strengthened enforcement but also increased the discretion of states over whether or not to "pass through" payments to families on public assistance (Garfinkel, 2001) . Recent evaluation evidence of a child support pilot project
} 
The likely effect of incarceration is to raise the tax rates on non-custodial fathers associated with child support. Pirog et al. (1998) estimates that the tax rates on earnings are generally in the $20-35 \%$ range for low-income fathers. However, for those in "arrears" - or in debt to the child support system - tax rates are generally as high as $65 \%$ (Edelman et al., 2006). These tax rates will then be supplemented by payroll, sales and other taxes on earnings (Primus, 2002). Furthermore, any non-custodial father who has been incarcerated will automatically be in arrears, as the child support orders remain in effect during their periods of incarceration.

Of course, the effects of the child support collection system and how it interacts with imprisonment reflect specific policy choices, which could be changed or offset by other policies. Thus, if states were to engage in "arrears management" that create better incentives for payment on current orders; ${ }^{6}$ or if the Earned Income Tax Credit (EITC) were more fully extended (by the federal or state governments) to this population to improve their work incentives in low-wage jobs; then the negative effects of arrears on work incentives of those previously incarcerated might be modified. We will discuss these possibilities more fully below; but, in the meantime, neither the federal government nor most states have implemented such policies. Thus, the vast majority of ex-offenders face very high tax rates on their meager earnings that likely reduce their legitimate work activity - at least if they can go undetected by the formal system of child support enforcement.

\footnotetext{
in Wisconsin also indicates that "pass through" effects the tendency of non-custodial fathers to pay support. See Cancian and Meyer (2006).

${ }^{6}$ For example, the high tax rates on arrears might be foregone if poor non-custodial fathers agree to pay their full current orders, and perhaps small percentages each year on what they owe from the past.
} 
While the net effects of incarceration on incentives to and rewards from work are thus somewhat mixed on the supply side of the labor market, their effects on employer demand for labor are unambiguously negative. Ceteris parabis, employers might be unwilling to hire those with criminal records for many reasons - such as the risk of legal liability if a previous offender harms a customer or coworker, the risk of financial liability if the offender engages in theft, fears of personal violence, and the negative signals that a period of incarceration sends about their general skills or trustworthiness. Given various legal rulings by courts about employer liability for physical or property damage generated by previous offenders whom they have hired (Holzer et al., 2004); and given the correlation between offender status and a range of health and educational characteristics (Travis, 2004); it might be perfectly rational for employers to engage in such behavior, even though some fears might also be exaggerated and based on stereotypes. It is also likely that these fears will be stronger for some types of jobs - such as those involving direct contact with customers, or the handling of cash - than for others. And the many state or federal laws that prohibit the hiring or licensing of those with criminal records into various occupations clearly reinforce these tendencies (Legal Action Center, 2004).

Clearly, these factors imply that a period of incarceration for any individual directly reduces his/her employability, above and beyond the effects of poor skills and work experience that they had prior to incarceration - in other words, that incarceration causes lower employer demand, controlling for other characteristics and behaviors of the individual that might have already reduced their employment. Once again, there are policy options (such as tax credits for employers who hire ex-offenders and bonding to 
protect them from legal and financial liabilities) that might potentially offset these negative effects; but, absent greater use of these policy offsets, the effects of previous incarceration on employer demand are likely negative.

Will this reduction in labor demand for ex-offenders definitely reduce employment outcomes for this group? While the reduction in potential opportunities is clear, its impact on actual employment outcomes depends on the magnitudes of the reductions in job offers for the offender population, and the size of the offender relative to non-offender labor forces (e.g., Becker, 1975; Heckman, 1998). If the numbers of offenders seeking employment are small, relative to the numbers of employers still willing to hire them; and if they have sufficient information about and access to these jobs; then it might be possible for offenders to find such employment and thus avoid being hurt by their offender status. On the other hand, if large numbers of men carry this stigma, relative to the number of available jobs; and if these men have limited information about where these other opportunities exist, or face additional barriers to being offered these jobs (because of skill deficiencies, “spatial mismatch” between locations of jobs and their own residences, weak informal networks, etc.), then the reduction in potential job offers might well translate into reduced employment and earnings outcomes for this population. ${ }^{7}$

Furthermore, the negative effects of incarceration on labor demand are not necessarily limited to those who have actually been incarcerated. Because job applicants have little incentive to directly inform prospective employers about their criminal histories; and because many employers do not check criminal background (since the

\footnotetext{
${ }^{7}$ See Holzer (2001) for a review of the evidence on the broader set of employment barriers faced by black men.
} 
checks are at least somewhat costly and potentially inaccurate); employers generally do not have perfect information about which applicants have or do not have criminal records. In such a situation, employers might well engage in a form of statistical discrimination, in which personal characteristics that are statistically correlated with offender status - such as being a less-educated black male - are used by employers to predict such status in the absence of the direct individual information. In these cases, they might tend to avoid hiring from some broader demographic groups (like black men), simply to avoid hiring ex-offenders inadvertently. ${ }^{8}$

In sum, an episode of incarceration could have either positive or negative effects on the subsequent employment of the offenders themselves, by virtue of its impacts on their incentives to work, their skills and their information or networks. Impacts on nonoffenders might be positive or negative as well. Incarceration almost certainly limits the interests of employers in hiring previous offenders (or those whom they think might be), though there remain questions about its relative magnitude and impact. Overall, the net impacts of all of these factors on the employment outcomes of workers who either have or have not been incarcerated remain unclear a priori.

The net effects of incarceration on employment, then, can only be ascertained by a careful review of the empirical evidence, to which we now turn.

\section{Empirical Evidence on Incarceration and Employment Outcomes}

In this section, we review the empirical evidence on the impacts of incarceration on employment outcomes for those with criminal records as well as other individuals.

\footnotetext{
${ }^{8}$ In other contexts, such discrimination might also be called racial profiling. For further evidence on statistical discrimination or racial profiling in the criminal justice system see Leung et al. (2004) and Close and Mason (2002).
} 
The studies we consider are summarized in Figure 2. Broadly, the studies fit into three categories: 1) Those focusing on the demand side of the labor market, or employer hiring behavior; 2) Those on the supply side, focusing on employment outcomes for individuals with and without criminal records; and 3) Those that use more aggregate state-level data to explore these effects. The studies focusing on the demand side of the market can be further subdivided into those using employer survey data v. those based on experimental "audits” of actual hiring behavior; while those on the supply side of the market can also be subdivided into those primarily using survey data v. administrative data.

\section{A. Demand-Side Studies}

As noted, one set of studies in this section (Holzer, Raphael and Stoll 2004, 2006, 2007) use employer survey data to analyze the demand for ex-offender labor. These studies are based on a set of employer surveys first administered by Holzer (1996) and later by Holzer, Raphael and Stoll (2007). The original survey was administered to about 3000 employers in four large metropolitan areas - Atlanta, Boston, Detroit, and Los Angeles - during the period 1992-94, as part of the Multi-City Study of Urban Inequality (sponsored by the Ford and Russell Sage Foundations). The followup survey was administered to about 600 employers only in Los Angeles in the year 2001.

Both surveys were based on size-weighted samples of firms, in which the distributions of firms across size categories were chosen to replicate the actual distribution of workers across firms in the labor force. The questions gauged employer willingness to hire a variety of workers with various stigmas - such as having a criminal

record, being a welfare recipient, having an unstable work history, etc. - into the job filled 
by the last worker hired at the firm. With considerable data on the characteristics of the firms as well as the jobs they were filling, the authors were able to consider the effects of both on their stated willingness to hire offenders. The survey also gauged whether or not employers perform criminal background checks when filling these jobs. The followup survey also asked about actual hiring of ex-offenders, as well as self-reported willingness to do so; and asked a more detailed set of questions about employer perceptions of offenders and their willingness to hire them.

The audit studies of employers use a methodology that has been widely used to measure employer discrimination at the hiring stage (e.g., Fix and Struyk, 1993; Neumark, 1996). In this method, matched applicant pairs of different race/ethnicity or gender but with otherwise equivalent credentials are sent out to apply for jobs; the relative tendency of applicants to receive "call backs," interviews or offers by race/ethnicity or gender is then used to measure discrimination against minorities or women whose credentials appear identical to those of white/male applicants.

Pager (2003) was the first to apply this methodology to the issue of offenders and non-offenders applying for jobs. She sent out roughly 200 matched pairs of black applicants (i.e., where one applicant purports to have a criminal record and one does not) and 150 pairs of white applicants to employers in Milwaukee. Pager and Western (2005) then applied a similar methodology to a larger sample of employers in New York City, with Hispanic offenders and non-offenders also included among the matched applicant groups.

There are some clear advantages and disadvantages to each type of employer study. The employer survey paints a broader portrait of how offenders are viewed in the 
labor market and how they are treated, relative to other disadvantaged groups. The detailed characteristics of firms and jobs also enable us to disaggregate how offenders are treated across various sectors of the labor market. In contrast, the "audit" studies more successfully control for unobserved characteristics of applicants, and can more clearly test causal claims about employer aversion to hiring offenders and minorities. They also measure actual employer behavior, and not merely what is reported.

But, as with any "experiment," there are questions about the extent to which the particular findings from these small samples of employers and applicants generalize to the broader population of offenders and the broader labor market, and whether any employer behavior measured really affects labor market outcomes. ${ }^{9}$ The Pager studies, in particular, raise a number of questions - such as whether or not the employers audited and the characteristics of applicants with criminal records are truly representative of the relevant actors in the labor market; and whether or not self-reported criminal records by auditors have the same impacts on employment as real records that show up in the employer background checks that have become quite prevalent (Holzer et al., 2007) ${ }^{10}$ If the participants are not representative, or self-reported criminal records are not treated the same by employers as real ones in background checks, biases in estimated effects may results - though their directions are not very clear. ${ }^{11}$

\footnotetext{
${ }^{9}$ See Heckman (1998) for a range of critiques of audit studies.

${ }^{10}$ For instance, Pager's employers are drawn primarily from help-wanted ads in newspapers, which draw more from the middle than the bottom of the skill distribution of workers and include more sales jobs than do other recruitment methods (Holzer, 1996). Her applicants all report high school diplomas and significant work experience, including some in a managerial capacity, which go beyond what most real ex-offenders can report. "Offenders" in her study also report just one non-violent felony drug offense.

${ }^{11}$ Offender status might be either more or less harmful to job applicants in a fuller sample of employers or with a sample of workers whose other characteristics more closely approximate those of actual offenders. If employers take self-reported criminal history less seriously than that generated by background checks (because of the incentive of applicants with records to hide their history in the former), the negative effects
} 
Yet, despite the differences between and relative strengths and weaknesses of both approaches, the results are quite clear: both show strong employer aversion to hiring men with criminal records. In the employer surveys, roughly 40 percent of employers would "definitely" or "probably" hire applicants with criminal records, whereas much higher percentages (i.e., 80-90 percent) would hire former welfare recipients, workers with little recent work experience or lengthy unemployment, and other stigmatizing characteristics. In the audit studies, the fractions of applicants receiving "call backs” or job offers falls by roughly half among whites with criminal records, and as much or more among blacks. ${ }^{12}$

In the employer survey data, there is wide variation across firms and jobs in willingness to hire offenders. Jobs requiring reading or writing, contact with customers, and handling cash are less open to offenders than jobs without these required tasks. More broadly, employers who need to "trust" the honesty and dependability of their applicants will likely be more averse to hiring from this population. Also, the nature of the offense and the recent experiences of the offenders also affect reported employer willingness to hire. For example, if employers are told that the offender has only one non-violent drug offense, and has participated successfully in recent work assignments, reported employer willingness to hire rises. Apparently, the kind of information provided to employers about the offenders can strongly affect their demand for these workers.

And, if applicants can "self-select” and apply for jobs predominantly with employers that are not averse to offenders, their employment prospects might not be

of these self-reports might be biased downwards, though whether this is more true for white or minority applicants is also unclear.

${ }^{12}$ For instance, in Milwaukee the presence of a criminal record reduced the fraction of whites receiving call-backs from 34 to 17 percent, while the comparable fractions for blacks were 14 and 5 percent. In New York, the comparable fractions for whites are 31 and 17 percent. 
greatly diminished by their having criminal records. This would, of course, require them to have sufficient information about employer preferences and hiring practices, both across and within sectors, to make such choices. And, even if they have such information, would there be sufficient numbers of jobs for all to be hired, and at wages comparable to what they would have earned absent their criminal records? While the fraction of jobs available to offenders with limited other barriers (like very poor skills and work experience, substance abuse or mental health problems, lack of labor market information and contacts, spatial disconnection from jobs, etc.) might be sufficient for most to gain some kind of employment with some moderate job search effort, the combination of additional barriers and their offender status might well limit job availability and/or earnings for this group.

There is also important variation in hiring behavior according to the race of the job applicant. The audit studies find that black offenders and non-offenders both receive many fewer offers than their white counterparts in each category; indeed, white offenders generally receive as many offers as black non-offenders. The authors of these studies interpret this as evidence that racial discrimination is at least as large a barrier to hiring as is offender status.

But Holzer, Raphael and Stoll also show that black non-offenders appear to be hurt by a form of statistical discrimination in which employers might suspect that they really are offenders. Their data show that, among employers who prefer not to hire offenders, the use of criminal background checks actually raises the likelihood that employers will hire black men, as they eliminate uncertainty about who really is or is not 
an offender. ${ }^{13}$ This reinforces the notion that information is a critical part of the hiring process for minorities with or without criminal backgrounds, and that labor market “intermediaries” who help link offenders to jobs and provide appropriate information to employers can improve these employment prospects.

Overall, the two sets of studies leave little doubt that men with criminal records and in particular black men - face much weaker demand for their labor than do comparable men without these records. They also imply that there is spillover of this stigma, in the form of statistical discrimination, against black male non-offenders as well. But whether this limited demand translates into worse employment outcomes, or instead can be offset through vigorous job search or other third-party interventions (like jobplacement assistance), remains unclear from these studies. To address these issues, we address studies using data from the supply side of the labor market.

\section{B. Supply-Side Studies}

In this section we focus on papers that measure the impact of ex-offender status on subsequent employment and earnings in the U.S. We omit studies that focus primarily on highly-educated or white collar offenders (e.g., Lott, 1992a,b; Waldfogel, 1994) and those that deal with offenders in other countries (e.g., Nagin and Waldfogel, 1995). Other review papers (e.g., Freeman, 1999; Western et al., 2001) have also reviewed these studies, though they lack some of the most recent papers considered below.

The supply-side studies listed in Figure 2 differ from one another along several critical dimensions. For instance, some are based on administrative data from state penal institutions that are merged with earnings data from state Unemployment Insurance (UI)

\footnotetext{
${ }^{13}$ For other evidence showing that employer use of tests can reduce statistical discrimination and therefore improve employment opportunities among blacks see Autor and Scarborough (2004).
} 
earnings records, while others are based on survey data with self-reported measures of incarceration, employment and earnings. Of the studies using administrative data, some do not contain a comparison or control group, and rely instead on comparisons of earnings pre- and post-incarceration. The samples vary in terms of the ages of offenders considered, the time period and locations in which the studies are conducted, and the length of time before and after incarceration during which individuals are observed. The studies also use a variety of methods to deal with various likely statistical biases, such as unobserved heterogeneity (or omitted variables) across workers (which could lead researchers to overstate the negative impacts of a criminal record on earnings, if those with records are weaker job applicants than apparently comparable workers without them) and measurement error in earnings or offender status (which might lead estimated impacts to be biased towards zero, especially if the measurement error in offender status is “classical”). ${ }^{14}$

\section{Survey Data}

In general, the studies using survey data (based almost completely on the National Longitudinal Survey of Youth, or NLSY, 1979 cohort) uniformly find substantial negative effects of incarceration on earnings and employment of individuals. The "first generation” of these studies, notably by Freeman (1992) and Grogger (1992), find quite large negative effects of arrests and/or imprisonment on the likelihood of employment for

\footnotetext{
14 "Classical," or purely random, measurement error in a dependent variable generates inefficient but unbiased estimates while it leads to biases towards zero in estimated coefficients in an independent variable. If the measurement error in either variable is correlated with other observational characteristics it might generate biased estimates, though the directions of the biases are not clear a priori. Self-reported offender status is well-known to be frequently understated, especially among minorities (e.g., Hindelang et al., 1981.)
} 
young men with records. ${ }^{15}$ These studies compare these men directly to comparable nonoffenders, controlling for observable characteristics like education and previous work experience.

The "second generation" of NLSY studies, notably by Western $(2003,2006)$ and Raphael (2007), follow offenders and non-offenders over much longer time periods and use more sophisticated statistical techniques to deal with unobserved characteristics of offenders and non-offenders as well as measurement error. For instance, both studies use individual-specific dummy variables within the longitudinal data to control for "fixed effects," which eliminates the effects of permanent personal characteristics for which they cannot control. Both also construct alternative samples of non-offenders who are "at risk" of offending, particularly since many were arrested or incarcerated some time after the periods during which they are used as comparison observations. Both also attempt to deal with measurement error on self-reported incarceration by using whether any interview took place in prison to measure incarceration. ${ }^{16}$

All of these "second generation" studies also find substantial negative effects of incarceration on reported employment and earnings. Western focuses primarily on wage levels and wage growth, and finds both significantly lower among those with criminal records than those without them, regardless of which specification he uses. ${ }^{17}$ Raphael

\footnotetext{
${ }^{15}$ Freeman finds that having been in prison reduces subsequent employment activity by 15 to 30 percentage points, or by roughly 20 to 40 percent. Grogger estimates that previous arrests account for roughly a third of the black-white employment gap among youth in the NLSY, and significantly more than that in a sample of California arrestees also analyzed in the paper.

${ }^{16}$ By relying only on the location at the time of the interview to determine incarceration, they still might have missed shorter episodes of incarceration.

${ }^{17}$ Western (2003) finds that his estimates of whether offenders experience any wage growth postincarceration are very sensitive to his inclusion of year dummies. But the gap in rates of wage growth between offenders and non-offenders is not sensitive to specification. Overall, he finds wage levels of offenders reduced by at least 16 percent and wage growth reduced by about a half percentage point per year, though the estimated impacts for blacks are smaller than for whites.
} 
considers both weeks worked and wage levels in his analysis, along with other measures of the "transition to adulthood" such as the tendency to live at home with parents or the tendency to marry. He finds all of these outcomes significantly lower among offenders than non-offenders as well, though his estimated negative impact on wages is smaller and less significant in some specifications than those estimated by Western with similar data. $^{18}$

\section{Administrative Data}

The studies based on administrative data paint a somewhat more mixed picture of the impacts of incarceration on subsequent earnings. Of these studies, one by Grogger (1996) stands apart from the rest. He uses data from the adult criminal justice system in California merged with UI earnings data from the period 1980-84. As a comparison sample, he also uses a group that was incarcerated subsequently to 1984, as did Raphael (and, to an extent, Western). He estimates the impact of being arrested, convicted, or going to jail (or state prison) on both quarterly earnings and the likelihood of employment, with or without fixed effects, for up to six quarters after the original justice “event.”

Generally, Grogger finds somewhat modest negative effects on employment and earnings of all of these outcomes, which are weaker after controlling for "fixed effects," and which generally fade away for most outcomes. However, negative impacts persist for

\footnotetext{
${ }^{18}$ Raphael estimates that weeks worked are reduced by at least 6 weeks per year, or about 15 percent, and by as much as 10 weeks (or 25 percent) in some specifications. Raphael's findings on wages are only weaker than Western's when he uses both fixed effects and a restricted sample of non-offenders who themselves ultimately become incarcerated; in this case, he finds an average reduction in wages of only 3 percent instead of 15 percent or more. Raphael speculates that his comparison sample is stricter than that of Western, who uses those at risk of incarceration (including those who report any contact with the criminal justice system) rather than those actually incarcerated for his alternative sample. It is also possible that the combination of fixed effects and measurement error leads to downward biased estimates in both studies (e.g., Freeman, 1984).
} 
those who have been jailed. The negative impacts of state imprisonment are even larger but also less reliable, as more of these men might still be incarcerated six quarters after the original observation. ${ }^{19}$ And, even among those jailed, some might be incarcerated (either in jail or in state prison) for the entire short period subsequent to incarceration (6 quarters) which he measures.

The other studies using administrative data differ somewhat from those of Grogger. In particular, Kling (2006) uses data from California and Florida; Pettit and Lyons (2007) use data from the state of Washington; Sabol (2007) uses data from Ohio; and Cho and Lalonde (2005) use data on women offenders from Illinois. In all of these cases, data from the state penal institutions from the 1990's are linked to UI earnings data. $^{20}$

The primary purposes of these studies are not necessarily to focus on the impacts of incarceration on employment, though these impacts are often inferred from these studies. Kling’s paper focuses primarily on the impact of the duration of incarceration, rather than its incidence, on the subsequent earnings for those incarcerated - in other words, he analyzes the effects of shorter or longer spells of imprisonment within the sample of the incarcerated, rather than the effect of being incarcerated per se. Also, Sabol's paper focuses mostly on how local labor market conditions affect labor market reentry. But inferences about the effects of incarceration on earnings have been drawn from both papers. By focusing on women rather than men, the paper by Cho and Lalonde

\footnotetext{
${ }^{19}$ Grogger finds that employment rates per quarter for those jailed are reduced by roughly 4 percentage points, or about 8 percent overall, as much as 6 quarters are the initial period of incarceration. Earnings are reduced by $\$ 170$ per quarter (1980 dollars), or by about 14 percent.

${ }^{20}$ See also Needels (1996) for a paper on the impacts of the duration of incarceration on a much smaller sample of prisoners released in Georgia.
} 
is also somewhat different (and much less representative of the incarcerated population) than the rest.

These studies (excluding Grogger's) also have some common findings. For one thing, they all show very low levels of employment and earnings among ex-offenders, with only 30-40 percent generally showing any employment per quarter, and with quarterly earnings often averaging \$2000 or so among those working. ${ }^{21}$ But this seems to be true before as well as after incarceration for most individuals. Surprisingly, all three studies show significant increases in employment and earnings during the period immediately after incarceration, relative to the period immediately before; but these gains then fade away over time.

After the initial gains fade, how do the offenders' employment and earnings compare to the period before incarceration? Here the studies present more mixed evidence. Pettit and Lyons find lower earnings (by 4-5\%), and lower employment once 10 quarters have elapsed since release. Sabol also finds that employment rates are lower than before release by 6-7 quarters beyond release, though he does not find this for earnings conditional on employment. Kling finds both employment and earnings to be comparable or slightly higher after release than before incarceration, regardless of the duration of incarceration, for at least two years after release and as much as six years. ${ }^{22}$ Cho and Lalonde find that initially positive post-prison effects (of about 5 percentage points in quarterly employment) have faded by the third full quarter after release.

\footnotetext{
${ }^{21}$ Among the female offenders studied by Cho and Lalonde, employment and earnings are even lower. Average employment rates are about $25 \%$ per quarter before incarceration, while mean and median earnings are about $\$ 1800$ and $\$ 1200$ per quarter respectively. Most of these women have 2-3 children and are single mothers.

${ }^{22}$ Kling analyzes data for 28 quarters (or 7 years) after the spells of incarceration begin, and he considers men with anywhere from 1-4 years of incarceration. The maximum spell of incarceration he considers is 53 months long, which leaves about 30 months of post-incarceration observations for these individuals, and much more for those incarcerated for shorter spells.
} 
The initial rise in employment and earnings after release does not appear in the studies using the NLSY, perhaps because these studies focus mostly on current hourly wages or weeks worked in the prior year; and it did not appear in Grogger's paper (1996) using administrative data. Maybe the discrepancies across these studies represents a timing issue - in that more stringent post-release supervision of parolees and stricter enforcement of child support orders in the 1990's leads to a temporary spurt of formal employment activity that didn’t occur earlier. ${ }^{23}$

But a number of problems plague all of the studies based on administrative data, at least insofar as we try to infer from them the impacts of incarceration on employment and earnings. For one thing, the UI records only capture earnings in formal jobs, especially those covered by UI in any state. That would automatically exclude public sector jobs, any employment that occurs in another state, any self-employment, and most importantly - any casual and informal work for cash. In many contexts, these limitations would not be terribly severe; but part-time and casual employment likely characterize much work among offenders and ex-offenders, both pre- and postincarceration. Indeed, the very low quarterly employment rates measured here are dramatically lower than those found in any of the NLSY studies, or any other surveys of those incarcerated. ${ }^{24}$ The self-reported earnings in the NLSY might also be measured with some error, though any bias towards underreporting is less clear in those data.

\footnotetext{
${ }^{23}$ Pettit and Lyons speculate that special employment efforts undertaken for those released in the state of Washington might generate these results, but it is less clear that these could also account for the results observed by Kling and Sabol in Florida and Ohio respectively.

${ }^{24}$ Surveys of offenders often indicate that up to two-thirds report some sort of employment activity at the time of arrest (e.g., Travis, 2004); and young men in the NLSY usually report employment rates of about .60 , or about 30 weeks worked per year, after incarceration (Freeman, 1992; Raphael, 2007).
} 
Indeed, studies that compare earnings measures among the disadvantaged in survey v. administrative data generally (though not always) find lower earnings among the latter. ${ }^{25}$

The exact directions of any resulting biases in estimated effects of incarceration from these different data sources also remain somewhat unclear. If measurement error in the survey data are more random than in the administrative data, that might create some greater inefficiency in estimates using the former (where earnings are the dependent variable), but no clear bias. For the administrative data, any biases in estimates of incarceration on earnings or employment would depend on whether the incidence of unreported employment is greater before or after incarceration. But the tendency to be casually employed is probably greater for younger than older workers, with the latter more represented in pre-incarceration samples. Furthermore, the tendency to underreport such work is probably somewhat lower right after incarceration, when attempts to meet parole and child support obligations through formal employment are likely to be most serious; if this is the case, the initial surge in employment right after incarceration might well be overstated, relative to what existed before incarceration (or afterwards), in which case the estimated impact of incarceration on these subsequent outcomes will be upward biased.

Another problem arises from the absence of a clear control or comparison group of non-offenders in at least some of these studies. Simple pre-post incarceration comparisons of employment and earnings outcomes may tell us little about the counterfactual situation that would have existed in the absence of incarceration.

\footnotetext{
${ }^{25}$ See Kornfeld and Bloom (1999), Hotz and Scholz (2001), and Piliavin et al. (2004). These studies tend to compare administrative and survey reports of earnings for workers in welfare or job training programs, mostly for the purposes of evaluating program impacts; none has focused on the incarcerated or on lowincome young men more broadly.
} 
Assuming at least some growth in earnings with labor market experience would have occurred absent incarceration, the simple pre-post test likely biases downwards any measured loss of earnings after incarceration.

To deal with this problem, Cho and Lalonde as well as Kling use preincarceration earnings of those ultimately incarcerated as a comparison group (as did Grogger, Raphael and Western in studies cited above) ${ }^{26}$ In both of these cases, we find little evidence of strong earnings growth before incarceration; if anything, we find some strong downward trends in the year or two before incarceration. But any such study must be careful to make sure that individuals have not been incarcerated at all in the period before administrative data on incarceration are available. Though Cho and Lalonde are careful to focus on first-time experiences of imprisonment, they note that women might have been incarcerated in local jails in the year or two preceding their first-time imprisonment in a state facility, thus reducing their measured earnings before incarceration.

Furthermore, these studies sometimes observe these individuals for fairly short time periods before incarceration; for instance, Kling's data from Florida provide just four quarters of pre-incarceration employment data. And they may not capture offenders early in the life-cycle when earnings growth is likely greatest. Indeed, Cho and Lalonde focus on women who are over 30 (on average) at the time of first incarceration - a

\footnotetext{
${ }^{26}$ Kling uses a difference-in-difference (DD) strategy to estimate the impact of imprisonment duration on earnings, for those whose prison spells occur before employment relative to those whose spells occur afterwards. But this is not the same as comparing earnings or employment levels overall for those who are incarcerated earlier v. later. Kling also uses an instrumental variables (IV) strategy here, using the identity of judges who tend to impose different sentence lengths as the instrument; but these estimates also tell us nothing about the effect of incarceration incidence.
} 
sample whose employment experiences may not be representative of the earnings potential of younger (and mostly male) offenders in the absence of incarceration.

For the comparison groups to be valid, they should involve similar age groups and be observed in the same time periods (or at least under similar labor market conditions) as those incarcerated earlier. These conditions are not always met in the administrative data studies. For instance, the Cho and Lalonde data compare pre-incarceration employment for women right before or during the implementation of welfare reform (i.e., 1995-97) to post-incarceration employment in the period right afterwards (1998-2000) though the former might well be downward biased compared to the latter.

While not perfect, the NLSY data on comparison groups do not so clearly suffer from these biases. ${ }^{27}$ Western's data clearly show earnings growth before incarceration among young men in the NLSY (after controlling for year effects). And other studies of low earners (e.g., Gladden and Taber, 2000) show earnings growth among the leasteducated workers that is at least comparable to that of the more-educated per unit of actual labor market experience.

These considerations suggest that the studies based on administrative data might well understate the negative impacts of incarceration on subsequent earnings or employment. The fact that at least some of these studies (except for Cho/Lalonde and Kling) still find such effects at some point after release from prison is therefore quite noteworthy.

\section{Studies Using Aggregate Data}

\footnotetext{
${ }^{26}$ For instance, the NLSY data begin observing most people in their teens, capturing critical periods of early labor market activity; and they also record all spells of incarceration (except for very short ones) that occur from that point on.
} 
At least one other problem arises in all of the supply-side studies. The demandside studies (especially those by Holzer, Raphael and Stoll) clearly suggest that, at least among young black men, the stigma associated with previous incarceration spills over onto those not incarcerated because of statistical discrimination when the exact identities of those incarcerated is uncertain. This implies yet another reason why measured gaps between the incarcerated and non-incarcerated may be biased downwards, and that incarceration might reduce employment and earnings among young unskilled men and especially black men more broadly.

This notion is tested in a recent paper by Holzer, Offner and Sorensen (2005). Pooling data from the Outgoing Rotation Groups of the Current Population Surveys (CPS-ORG) between 1979 and 2000, they analyze the effects of incarceration rates of black men (as well as child support enforcement activities) by state and year on the employment and labor force activity of all young black men (aged 16-24 and 25-34) with high school or less education. The incarceration rates are lagged by three years, to estimate the flows of offenders back into the noninstitutional population. ${ }^{28}$ Equations for employment and labor force participation of individuals were estimated as functions of these state-level variables, as well as controls for personal characteristics (such as age and education), metropolitan area labor force characteristics (such as local unemployment rates, industrial composition of employment, and percent female or Hispanic in the local workforce), and year and state dummies.

\footnotetext{
${ }^{28}$ The average length of a spell of incarceration for those released in the 1990's was roughly 3 years. But estimated results were not very sensitive to the length of this lag. It is also important to remember that, while the individuals are actually incarcerated, they do not show up in the CPS data on those not institutionalized. Even after release, those incarcerated likely contribute to the well-known "undercount" of black men in CPS data (Baker and Schmitt, 2006), implying again that estimated effects of previous incarceration on employment using these data might be downward biased.
} 
The results clearly showed that previous incarceration was associated with large declines in employment and labor force participation among young black men. Indeed, for every percentage point rise in the overall incarceration rate of black men, employment and labor force participation in the noninstitutional population declined by a percentage point or more. ${ }^{29}$ Of course, it is possible that these results pick up some endogeneity of incarceration with respect to employment rates, or some unobserved state-level characteristics correlated negatively with employment and positively with incarceration. But the presence of state and time fixed effects and substantial controls for local labor markets render this interpretation somewhat unlikely. Estimates using "difference-indifference” (DD) techniques, in which any effects found for whites are attributed to omitted variables and only the differences between blacks and whites are considered true causal effects, are similar to those generated by ordinary least squares (OLS) regressions. And a variety of Hausman tests presented in the paper are also consistent with the notion that these results capture real causal effects of previous incarceration on employment. ${ }^{30}$

\section{Summing Up: Directions and Magnitudes of Impacts}

The above discussion indicates that the high rates of imprisonment in the U.S. reduce employment opportunities (i.e., employer demand for their labor) for those who have been incarcerated and even for some of those who have not been. Whether these reduced opportunities actually translate into reduced employment and earnings outcomes is a little less clear, though the preponderance of the evidence considered suggests that it

\footnotetext{
${ }^{29}$ Estimated impacts of child support enforcement on employment for this group were more mixed, though more clearly negative for labor force participation of men aged 25-34. But any impacts of child support enforcement on the outcomes of men in states with high levels of incarceration are likely captured by those variables.

${ }^{30}$ The Hausman tests use two instrumental variables: one created by Steven Levitt (2001) to capture prison overcrowding litigation as an exogenous determinant of incarceration, and another generated by Kevin Reitz (2004) to capture state-level sentencing laws. For more detail on Hausman tests see Wooldridge (2005).
} 
does. Studies using either self-reported survey data or more aggregated state-level findings from the CPS clearly imply reduced employment and/or earnings, while at least some (though not all) of the studies using administrative data on imprisonment and earnings suggest this as well. Other studies of more highly-educated prisoners in the U.S. (by Lott and by Waldfogel, noted above) also have similar findings.

How large are these negative effects? As noted earlier, the findings by Holzer et al. (2005) imply that each extra percentage point of imprisonment of black men overall is associated with a decline in employment or labor force participation of 1.0-1.5 percentage points among younger black men. ${ }^{31}$ Since each percentage point of current incarceration of black men translates into 5-6 points of previous incarceration for young black men, the estimates imply that each additional percentage point of previous offender status reduces employment by about .17-.30 percentage points for black men, and that the overall levels of earlier incarceration inferred for this population reduce employment activity by 4-9 percentage points. $^{32}$ These estimates are roughly consistent with those by Western, Raphael and Freeman (noted above) using data from the NLSY. They also imply that the increases in incarceration since 1980 have reduced young black male labor force activity by 3-5 percentage points.

Whether these effects are as large for white and Latino men (or women) is not as clear, though most studies show effects on those groups as large or larger than those for black men. And any effects on wages, which (according to Raphael and Western) are

\footnotetext{
${ }^{31}$ This represents the range of estimates generated by DD techniques. Those using OLS were a bit smaller for employment and comparable for labor force participation.

${ }^{32}$ Overall incarceration rates for black men out of their population were roughly 5 percent by 2000, while the percentages of young black men with criminal records have been estimated to be 25-30 percent by Raphael, Western and others. See also Bonczak (2003). Thus, the 1.0-1.5 percentage point drop translates into a range of $1 / 6$ to $1.5 / 5$, or .17-.30 percentage points, of lost employment for those with records; and, since .25 to .30 of young black men have these records, this implies reduced employment activity of 4-9 percentage points.
} 
reduced by anywhere from 3 to 16 percent for this population, further add to the collateral costs of incarceration.

\section{Conclusion}

In this paper, I review the empirical evidence on one of the primary “collateral consequences” of mass imprisonment - namely, the effects of incarceration on subsequent employment and earnings.

At least theoretically, these impacts could be positive or negative. By deterring crime and even by spurring some additional educational attainment among prisoners, it is at least possible that incarceration could have positive effects. But, by reducing their work experience, labor market contacts, and incentives to work (especially among those with child support arrearages), incarceration might well have negative effects on labor force activity. The likely negative effects of incarceration on employer demand compound this likelihood, though it is unclear whether or not these effects are large enough to actually translate into lost earnings.

Our review of the empirical evidence suggests that, despite the mixed nature of the findings reviewed, the net effects of incarceration on employment and earnings are likely negative. Studies of employer behavior - either from general surveys or from “audits” with matched pairs of applicants with and without criminal records - all strongly show that have a criminal record reduces labor demand. Among less-educated black men, the data suggest that the effects of incarceration also "spill over" onto the nonincarcerated, reducing their job opportunities as well. 
Studies of individual workers using survey data - primarily from the NLSY imply reduced earnings and employment for those who have been incarcerated. The most recent of these studies use more sophisticated statistical techniques to control for omitted variables and for measurement error in incarceration, and they still generate these findings. Studies using micro-level administrative data are more mixed, in terms of results. But I find these less useful for inferring the impacts of incarceration, mostly because they miss so many informal jobs (and, more generally, even formal jobs not covered by Unemployment Insurance); also, they often lack appropriate comparison groups with which to infer the counterfactual experiences of nonincarceration for those who have been jailed. Still, at least some of these studies find negative effects of incarceration on post-release employment or earnings, relative to their pre-release level, at some point in time. And more aggregated data at the state level show that incarceration reduces subsequent employment among young black men broadly, including those who have not been incarcerated themselves; this type of study avoids the bias towards zero in cross-sectional estimates based on individual comparisons, because of the likely spillovers of employer attitudes towards the incarcerated onto the non-incarcerated.

Of course, there are other "collateral costs" to incarceration that we do not address in this paper. Reduced employment and earnings of fathers certainly reduce the family incomes of their children, and may have important intergenerational effects well beyond those measured here. The lost employment in neighborhoods and communities likely weakens employment networks and, more broadly, norms about work that suggest wider negative impacts. Legislated restrictions on the availability of various public benefits like Pell Grants, public housing and Food Stamps - to those with criminal records imply 
additional costs to the individuals and their families. And reductions in civic participation - including voting (Uggen and Manza, 2002) and other community activities - represent additional costs associated with incarceration.

Further research is clearly needed to quantify these many costs, and compare them with the benefits associated with incarceration in terms of reduced crime. But the estimates described here suggest that current levels of incarceration have substantial costs that policymakers should try to limit. One way or doing so might be to reduce rates of incarceration, if we judge that these currently go beyond some social optimum (as John Donohue's paper in this volume suggests).

Alternatively, we might try to reduce the negative effects on employment associated with incarceration. Programs to support prisoner "reentry," both before and especially right after their release, seek to do so. Virtually all of these programs rely on labor market "intermediaries" to improve the access of offenders to employers, to improve offender basic skills or work readiness, and to provide employers with more accurate information about their recent work-related activities. Some, like the Center for Employment Opportunities (or CEO) in New York also provide the ex-offenders with paid “transitional jobs” for several months (MDRC, 2006).While our knowledge of exactly what is cost-effective in this regard remains somewhat limited (Bushway, 2003), we should continue to explore the various programs that exist and to rigorously evaluate them.

Other state and federal policies might also be useful in this regard. For instance, states can be encouraged to reconsider the many barriers they often put in place that limit the access of ex-offenders to employment or occupational licensing in a variety of 
sectors. Also, state-level child support policies might also be reconsidered - especially whether arrearages should be readjusted or even “forgiven” for men meeting their current orders, and whether collected payments should be "passed through" to families that have been on public assistance.

More effective tax credits and bonding might be provided to employers to offset the negative impacts of criminal history on their labor demand. Evidence on the Work Opportunity Tax Credit (WOTC) for employers of disadvantaged workers suggests limited takeup by employers and very limited effectiveness in raising employment of disadvantaged workers over time (Hamersma, 2007), though no such evidence has been provided for ex-offenders per se. ${ }^{33}$ On the supply side, an extension of the EITC to lowincome men and women without custody of children would likely help offset at least some of the negative incentive effects of incarceration, though its impacts would likely depend on exactly how such a policy is administered. ${ }^{34}$

Much further research and evaluation thus remains to be done. But the large costs on employment associated with current levels of incarceration need to be acknowledged and addressed through some remedial policy and programmatic activity.

\footnotetext{
${ }^{33}$ Katz (1998) provides some evidence that the Targeted Jobs Tax Credit (TJTC), an earlier version of the WOTC, might have successfully raised employment rates among some disadvantaged workers. On the other hand, the potential of the tax credits themselves to stigmatize applicants (Burtless, 1985) might also limit the effectiveness of any such approach.

${ }^{34}$ For two possible proposals see Berlin (2007) and Edelman et al. (2006). These proposals are reviewed and analyzed in Raphael (2007a).
} 


\section{References}

Autor, David and David Scarborough. 2004. "Will Job Testing Harm Minority Workers?” National Bureau of Economic Research Working Paper No. 10763.

Baker, Dean and John Schmitt. 2006. "The Impact of Undercounting in the Current Population Survey.” Center for Economic Policy Research, Washington D.C.

Becker, Gary. 1975. The Economics of Discrimination. Chicago: University of Chicago Press, $2^{\text {nd }}$ Edition.1975.

Becker, Gary. 1968. “Crime and Punishment: An Economic Approach.” Journal of Political Economy. 76: 169-217.

Berlin, Gordon. 2007. "Rewarding the Work of Individuals: A Counterintuitive Approach to Reducing Poverty and Strengthening Families. MDRC Working Paper.

Bonczar, Thomas. 2003. Prevalence of Imprisonment in the U.S. Population, 1974-2001. Washington D.C.: Bureau of Justice Statistics.

Burtless, Gary. 1985. "Are Targeted Wage Subsidies Harmful? Evidence from a Wage Voucher Experiment.” Industrial and Labor Relations Review. Vol. 39, 105-114.

Bushway, Shawn. 2003. "Reentry and Prison Work Programs.” Paper presented at the Urban Institute Reentry Roundtable, New York University, May 21.

Cancian, Maria; Daniel Meyer and Jen Roff. 2006.“The Effect of Child Support Pass-Through and Disregard Policies.” Unpublished, Institute for Research on Poverty, University of Wisconsin.

Cho, Rosa and Robert Lalonde. 2005. "The Impact of Incarceration in State Prison on the Employment Prospects of Women.” IZA Discussion Paper No. 1792, Bonn.

Close, Billy and Patrick Mason. 2002. Traffic Stop Data Analysis: The Florida Highway Patrol and Racial Differences in Traffic Stops and Driver Treatment. Report to the Florida Department of Transportation.

Donohue, John. 2007. Paper in this volume.

Edelman, Peter; Harry J. Holzer and Paul Offner. 2006. Reconnecting Disadvantaged Young Men. Washington D.C.: Urban Institute Press.

Ehrenberg, Ronald and Robert Smith. 2000. Modern Labor Economics. New York: Addison Wesley and Longman. 
Fix, Michael and Raymond Struyk. 1993. Clear and Convincing Evidence. Washington D. C.: Urban Institute Press.

Freeman, Richard. 1992. "Crime and the Employment of Disadvantaged Youths.” In G. Peterson and W. Vroman eds. Urban Labor Markets and Job Opportunity. Washington D.C.: Urban Institute Press.

Freeman, Richard. 1999. "The Economics of Crime.” In O. Ashenfelter and D. Card eds. The Handbook of Labor Economics. Vol. 3. Amsterdam: North Holland., 3529$-71$.

Freeman, Richard. 1984. "Longitudinal Analyses of Trade Unionism.” Journal of Labor Economics. 2:1-18.

Garfinkel, Irwin. 2001. "Child Support in the New World of Welfare.” In R. Blank and R. Haskins eds. The New World of Welfare. Washington D.C.: Brookings Institution, 442-60.

Gladden, Tricia and Christopher Taber. 2000. In D. Card and R. Blank eds. Finding Jobs: Work and Welfare Reform. New York: Russell Sage Foundation, pp.16092.

Granovetter, Mark. 1974. Getting a Job: A Study of Careers and Contacts. Cambridge MA: Harvard University Press.

Grogger, Jeffrey. 1992. "Arrests, Persistent Youth Joblessness, and Black/White Employment Differences.” Review of Economics and Statistics. 74:100-06.

Grogger, Jeffrey. 1998. “Market Wages and Youth Crime.” Journal of Labor Economics. 16:756-91.

Grogger, Jeffrey. 1996. "The Effects of Arrests on the Employment and Earnings of Young Men.” Quarterly Journal of Economics, 110:51-72.

Hamersma, Sarah. 2007. "The Effects of an Employer Subsidy on Employment Outcomes: A Study of the Work Opportunity and Welfare-to-Work Tax Credits." Unpublished, University of Florida.

Heckman, James. 1998. “Detecting Discrimination.” The Journal of Economic Perspectives. 12:101-16.

Hindelang, Michael; Travis Hirschi and Joseph Weis. 1981. Measuring Delinquency. Beverly Hills CA: Sage Publications.

Holzer, Harry J. 1996. What Employers Want: Job Prospects for Less-Educated Workers. New York: Russell Sage Foundation. 
Holzer, Harry J. 2001. "Racial Differences in Labor Market Outcomes Among Men.” In N. Smelser, W.Wilson and F. Mitchell eds. America Becoming: Racial Trends and their Consequences. Washington D.C.: National Academy Press.

Holzer, Harry J. “Informal Job Search and Black Youth Unemployment.” American Economic Review. 77: 446-52.

Holzer, Harry J.; Paul Offner and Elaine Sorensen. 2005. Declining Employment among Young Black Men: The Role of Incarceration and Child Support.” Journal of Policy Analysis and Management. 24: 329-50.

Holzer, Harry J.; Steven Raphael and Michael Stoll. 2004. "Will Employers Hire Former Offenders? Employer Preference, Background Checks and their Determinants.” In M. Pattillo, D. Weiman and B. Western eds. Imprisoning America: The Social Effects of Mass Incarceration. New York: Russell Sage Foundation.

Holzer, Harry J.; Steven Raphael and Michael Stoll. 2006. "Perceived Criminality, Criminal Background Checks and the Racial Hiring Practices of Employers.” Journal of Law and Economics. 49: 451-80.

Holzer, Harry J.; Steven Raphael and Michael Stoll. 2007. "The Effect of an Applicant's Criminal History on Employer Hiring Decisions and Screening Practices: New Evidence from Los Angeles. In S. Bushway, M. Stoll and D. Weiman eds. Barriers to Reentry? The Labor Market for Released Prisoners in Post-Industrial America. New York: Russell Sage Foundation.

Hotz, V. Joseph and J. Karl Scholz. 2001. "Measuring Employment and Income for Low-Income Populations with Administrative and Survey Data.” In Studies of Welfare Populations: Data Collection and Research Issues. Washington DC: National Academy of Sciences.

Ioannides, Yannis and Linda Datcher Loury. 2004. Journal of Economic Literature. 42:1056-93.

Jones, Michelle Ganow. 2002. “Options to Help Low-Income Non-Custodial Fathers Manage their Child Support Debts.” Welfare Information Network Issue Notes, Vol. 6, No. 7.

Juhn, Chinhui; Kevin Murphy and Robert Topel. 1991. "Why Has the Natural Rate of Unemployment Increased Over Time?” Brookings Papers on Economic Activity, 2: $75-142$.

Katz, Lawrence. 1998. "Wage Subsidies for the Disadvantaged.” In R. Freeman and P. Gottschalk eds. Generating Jobs. New York: Russell Sage Foundation. 
Kling, Jeffrey. 2006. Incarceration Length, Employment and Earnings. American Economic Review. 96: 863-76.

Kornfeld, Robert and Howard Bloom. 1999. "Measuring Program Impacts on Employment and Earnings: Do UI Wage Reports from Employers Agree with Surveys from Individuals?” Journal of Labor Economics, 17: 168-97.

Legal Action Center. 2004. After Prison: Roadblocks to Reentry. New York City.

Lott, John. Do We Punish High Income Criminals Too Heavily? Economic Inquiry, 30: 583-60.

Lott, John. "An Attempt at Measuring the Total Monetary Penalty from Drug Convictions: The Importance of an Individual's Reputation.” Journal of Legal Studies, 21: 159-87.

Leung, Ambrose; Frances Woolley, Richard Tremblay and Frank Vitaro. 2005. "Who Gets Caught? Statistical Discrimination in Law Enforcement. Journal of SocioEconomics. 34: 289-309.

Levitt, Steven. 1996. "The Effect of Prison Population Size on Crime Rates: Evidence from Overcrowding Litigation.” Quarterly Journal of Economics. 111:319-52.

Ludwig, Jens. 2006. “The Costs of Crime.” Testimony to the U.S. Senate Committee on the Judiciary, September 19.

MDRC. 2006. The Power of Work: The Center for Employment Opportunity Comprehensive Prisoner Reentry Program. New York.

Mincy, Ronald and Elaine Sorensen. 1998. "Deadbeats or Turnips in Child Support Reform.” Journal of Policy Analysis and Management. 17: 44-51.

Nagin, Daniel and Joel Waldfogel. 1995. "The Effects of Criminality and Convctions on the Labor Market Status of Young British Offenders.” International Review of Law and Economics. 15: 109-26.

Needels, Karen. 1996. "Go Directly to Jail and Do Not Collect? A Long-Term Study of Recidivism, Employment and Earnings Patters among Prison Releases.” Journal of Research in Crime and Delinquency. 33:471-96.

Neumark, David. 1996. "Sex Discrimination in Restaurant Hiring: An Audit Study.” Quarterly Journal of Economics. 111:915-42.

Pager, Devah. 2003. The Mark of a Criminal Record. American Journal of Sociology. 108: 937-75. 
Pager, Devah and Bruce Western. 2005. "Discrimination in Low-Wage Labor Markets: Evidence from an Experimental Audit Study in New York City.” Paper presented at the Population Association of America Meetings.

Pirog, Maureen; M. Klotz and K. Byers. 1998. "Interstate Comparisons of Child Support Orders Using State Guidelines.” Family Relations. 47: 289-95.

Primus, Wendell. 2002. "Improving Public Policies in Order to Increaes the Income and Employment of Low-Income Non-Custodial Fathers.” Center on Budget and Policy Priorities, Washington D.C.

Pettit, Becky and Christopher Lyons. 2007. "Status and the Stigma of Incarceration: The Labor Market Effects of Incarceration by Race, Class and Criminal Involvement.” In S. Bushway, M. Stoll and D. Weiman eds. Barriers to Reentry? The Labor Market for Released Prisoners in Post-Industrial America. New York: Russell Sage Foundation.

Piliavin, Irving; Amy Dworsky and Mark Courtney. 2004. "Measuring Employment and Earnings among Low-Income Populations: Survey or Administrative Data?” Unpublished paper, University of Wisconsin.

Raphael, Steven. 2007a. "Boosting the Earnings and Employment of Low-Skilled Workers in the United States: Making Work Pay and Removing Barriers to Employment and Social Mobility.” Unpublished, University of California at Berkeley.

Raphael, Steven. 2007b. "Early Incarceration Spells and the Transition to Adulthood.” In S. Danziger, F. Furstenberg and C. Rouse eds. The Price of Independence. New York: Russell Sage Foundation. In S. Bushway, M. Stoll and D. Weiman eds. Barriers to Reentry? The Labor Market for Released Prisoners in PostIndustrial America. New York: Russell Sage Foundation.

Raphael, Steven and David Weiman. 2007. “The Impact of Local Labor Market Conditions on the Likelihood that Parolees are Returned to Custody.”

Rees, Albert. 1966. "Information Networks in Labor Markets.” American Economic Review. 56: 559-66.

Reitz, Kevin. 2004. "Questioning the Conventional Wisdom of Parole Release Authority.” In M. Tonry ed. The Future of Imprisonment in the $21^{\text {st }}$ Century. London: Oxford University Press.

Sabol, William. 2007. Local Labor Market Conditions and Post-Prison Employment Experiernce of Offenders Released from Ohio Prisons. In S. Bushway, M. Stoll and D. Weiman eds. Barriers to Reentry? The Labor Market for Released Prisoners in Post-Industrial America. New York: Russell Sage Foundation. 
Sampson, Robert and John Laub. 1993. Crime in the Making: Pathways and Turning Points in Life. Cambridge MA: Harvard University Press.

Travis, Jeremy. 2004. But They All Come Back. Washington D.C.: Urban Institute Press.

Tyler, John and Jeffrey Kling. 2007. "Prison-Based Education and Reentry into the Mainstream Labor Market.” In S. Bushway, M. Stoll and D. Weiman eds. Barriers to Reentry? The Labor Market for Released Prisoners in Post-Industrial America. New York: Russell Sage Foundation.

Uggen, Chris and Jeffrey Manza. 2002. "Democratic Contraction? The Political Consequences of Felon Disenfranchisement Laws in the U.S.” American Sociological Review. 67: 777-803.

Waldfogel, Joel. 1994. "The Effect of Criminal Conviction on Income and the Trust "Reposed in the Workmen.”” Journal of Human Resources. 29:62-81.

Western, Bruce. 2006. Punishment and Inequality in America. New York: Russell Sage Foundation.

Western, Bruce. 2002. "The Impact of Incarceration on Wage Mobility and Inequality.” American Sociological Review. 67: 526-46.

Western, Bruce; Jeffrey Kling and David Weiman. 2001. "The Labor Market Consequences of Incarceration." Crime and Delinquency. 47:410-27.

Wilson, William J. 1996. When Work Disappears. New York: Alfred Knopf.

Wooldridge, Jeffrey. 2005. Introductory Econometrics: A Modern Approach. New York: South Western. 
Figure 1

\section{Potential Impacts of Incarceration on Labor Market Outcomes}

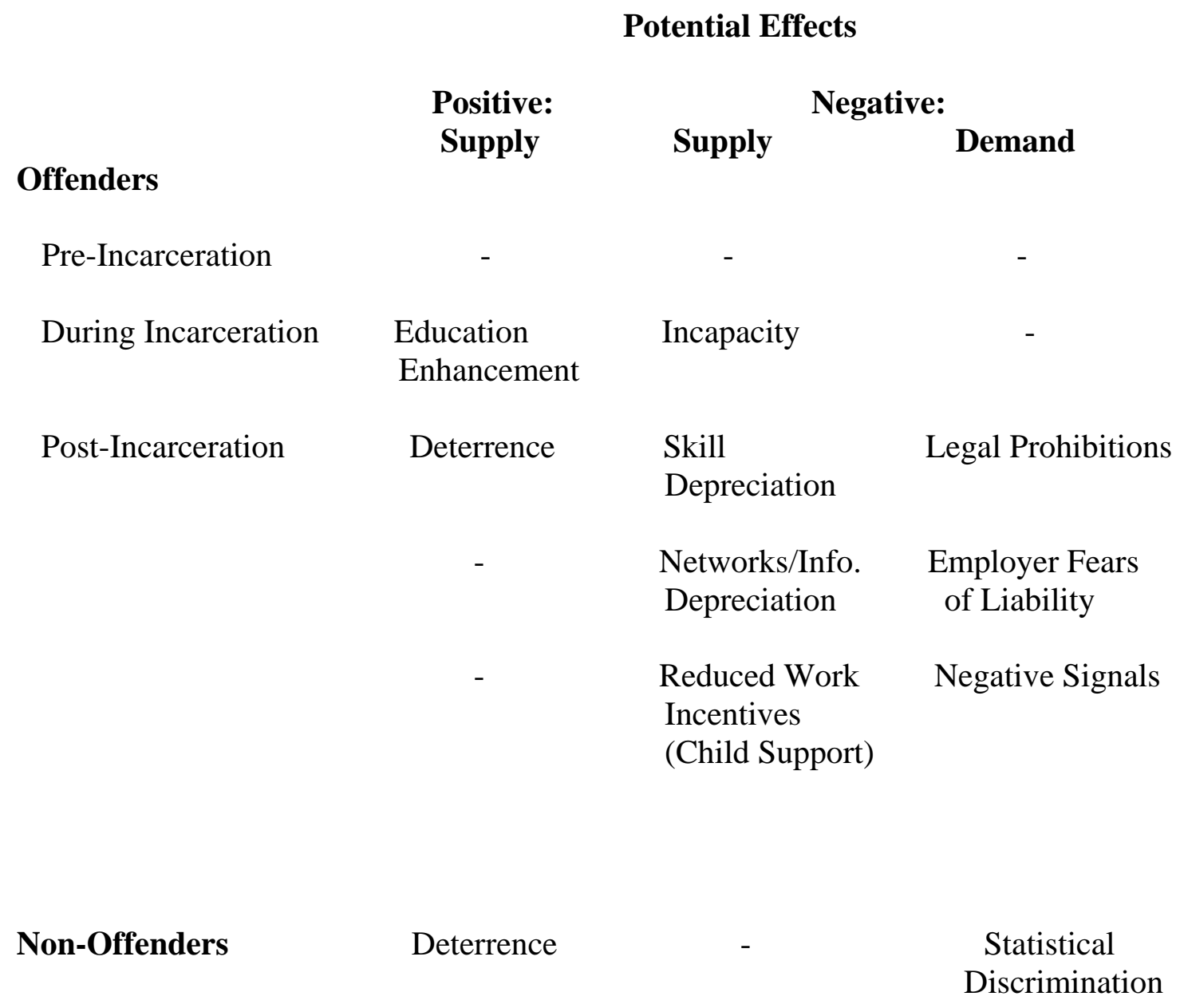




\section{Figure 2}

\section{Empirical Studies of Incarceration Impacts on Subsequent Earnings: Less-Educated U.S. Prisoners}

\section{Author Data Source Comparison Group? Finding:}

1. Labor Demand

Holzer, Raphael

And Stoll

$\begin{array}{llcc}\text { Pager } & \text { Hiring Audits } & \text { Yes } & \text { Yes } \\ \text { Pager and Western } & \text { Hiring Audits } & \text { Yes } & \text { Yes }\end{array}$

2. Labor Supply

Freeman

NLSY

Yes

Yes

Grogger (1992)

NLSY

Yes

Yes

Raphael

NLSY

Yes

Yes

Western

NLSY

Yes

Yes

Cho and Lalonde

Administrative: IL

Yes

No

Grogger (1996)

Administrative:

CA (1980s)

Kling

Administrative:

FL (1990s)

Pettit and Lyons

Administrative:

WA (1990s)

Sabol

Administative:

$\mathrm{OH}$ (1990s)

\section{Aggregate}

Holzer, Offner

And Sorensen
CPS-ORG, 1979-2000
Yes

Yes

\footnotetext{
${ }^{35}$ Negative impacts were observed on average earnings, and on employment rates after 10 quarters beyond release.

${ }^{36}$ Negative impacts were observed on employment after 6 quarters beyond release.
} 